\title{
On the Key Factors of the Chinese Listed Companies Financing Decisions of Issuing Medium Term Notes
}

\author{
Kan Zhang \\ School of Finance, Zhongnan University of Economics and Law, Wuhan, Hubei, PR China \\ Yi Liu \\ Research Center for Education Information, Huazhong Normal University, Wuhan, Hubei, PR China \\ Pan Xiao, Linzi Chen \\ School of Finance, Zhongnan University of Economics and Law, Wuhan, Hubei, PR China
}

\begin{abstract}
Based on the companies issuing Medium Term Notes (MTNs) listed at Shanghai Stock Exchange (SSE), this paper applies the Logistic model and pair sample analysis to study the key factors that determines the listed companies financing decisions of issuing MTNs from enterprise's business conditions, financial statements and corporate governance. The results show that company size, development prospect, financial leverage and ownership concentration have great effect on the decisions of issuing MTNs. In other words, the bigger companies size, the better development prospect, the lower financial leverage, the better corporate governance, the higher probability to issue MTNs.
\end{abstract}

KEYWORD: Medium Term Notes; Development Prospect; Financial leverage; Corporate governance

\section{INTRODUCTION}

Compared to the past long-term debt financing, Medium Term Notes (MTNs) have raised widespread concern and developed rapidly for simple and convenient approval process, low financing costs and normative market-oriented operation mode in China. From 2009, MTNs have exceeded enterprise bonds and corporate bonds on financing scale continuously, and have become Chinese listed companies' important source of funds in China. This paper studies the key factors that listed companies choose MTNs as direct debt financing instruments from the aspect of companies financing decisions.

\section{LITERATURE REVIEW}

Some scholars started studying the factors of companies debt financing decisions at an earlier time. Baxter and Crag (1970) argue that the larger scale a company has, the more likely to financing by the issuance of bonds. Krishnaswami et al. (1999) think that companies with high financial leverage are more likely to avoid banks intervening company management activities by public issuing bonds. Denis and Mihov (2003) consider that the creditworthiness of the issuer determines the debt source and the choice of debt financing is also affected by management decisions. Datta et al. (2000) thought large-scale companies with capital expenditures, assets and sales grow at the same time are more likely to choose debt financing. Mizen and Tsoukas (2013) find that factors which reflect companies' characteristic and the government policies have a significant impact on companies decision to issue bonds in Asian nine countries and regions.

Overall, foreign scholars have found a variety of factors to identify the impact of enterprises debt financing from company characteristics, financial indicators, management, government policies, but it is relatively limited to the specific research of MTNs financing decisions.

Compared with the mature foreign MTNs market, the history of China's MTNs market development is shorter, the related research still lags behind. But researches on the factors affecting the debt financing also have raised attention to Chinese scholars, and they used Chinese listed companies as samples to do research.

$\mathrm{Xu}$ and Chen (2001) consider the long-term financial leverage has a significant negative impact on the company's performance. Xiao and Wu (2002) find there is a positive correlation between company size and the level of debt. $\mathrm{Xu}$ (2006) find that the higher the proportion of a company' large

Project supported by the Fundamental Research Funds for the Central Universities (31540910508) and Hubei Finance Research Center (2011005). 
shareholders is, the better the company's operating performance will be. By comparison, companies with good operating performance are easier to achieve debt financing. Guo and Ma (2009) consider that for the companies with sufficient cash flow rely on low-cost internal funds financing first and less rely on costly external funds. Liao (2011) study the relevant factors of companies issuing MTNs from a financial characteristics perspective.

In a word, Chinese scholars have got consistent conclusions in the impact of company size, financial leverage, cash flow and other factors. But they still have different opinions on the influence of corporate governance and debt structure on the company's debt financing. Therefore, based on existing research, this paper not only considers the traditional factors of listed companies' debt financing, but also does further research on the influences that development prospect, ownership concentration, equity properties, debt structure and other factors to MTNs financing decisions of listed companies.

\section{MODELS}

\subsection{Model Selection}

This paper uses the Logit model to investigate the factors that determine the listed companies financing decisions of issuing MTNs. Let $p$ be the probability of listed companies to issue MTNs, the value is between 0 and 1,0 is the probability of not issuing MTNs, let the ratio $p$ / (1-p) be natural logarithm, and then get $\ln [p /(1-p)]$, that is the transformation of the Logit, named Logit (p), so Logit model is created:

$$
\operatorname{Logit}(p)=\alpha+\beta X_{i}+\lambda Y_{j}+\varepsilon
$$

Where $\mathrm{p}$ represents the probability of listed companies to issue MTNs, when issuing MTNs taken 1 , not to issue taken $0 . X_{i}$ represents various explanatory variables, including company size, development prospect, cash flow, financial leverage, the agent variables of ownership concentration and equity property. $Y_{j}$ represents various controlled variables, including main business profitability, overall profitability, growth capacity, company age and industry dummies. $\alpha$ is constant term, $\beta$ and $\lambda$ are regression coefficient vector sets of explanatory variable and controlled variable. $\varepsilon$ represents the residual of the Logistic model.

\subsection{Assumptions}

Based on the corporate finance theory, combined with the actual Chinese stock market, this paper will put forward the following assumptions:
Assumption 1: The larger the companies are, the higher the probability of issuing MTNs is.

Assumption 2: If Tobin's $Q$ is greater, the company's growth prospects will be better and the probability of issuing MTNs will be lower.

Assumption 3: The companies with higher financial leverage have the lower probability to issue MTNs.

Assumption 4: The more sufficient cash flow a company has, the lower probability for it to issue MTNs is.

Assumption 5: The larger debt structure a company has, the greater probability for it to issue MTNs is.

Assumption 6: The higher the proportion of major shareholders is, the higher the probability for companies to issue MTNs is.

Assumption 7: If the property of a company' major shareholders is non-state-owned, the company has the higher probability to issue MTNs.

\section{DATA AND EMPIRICAL RESULTS}

\subsection{Sample Selection}

In this paper, the A-share listed companies issued medium-term notes were screened, screening time is April 15, 2008 to December 31, 2011. A company which issued more than a MTN within a year is regarded as a sample and a company which issued MTNs in different years are regarded as different samples. Finally, we get a total of 74 valid samples. For each sample company, the paper selects a listed company which do not issue MTNs as a pairing company.

On the selection of pairing companies, we use the following criteria: firstly, all the financial data are derived from the issued bulletins of MTNs issuing sample companies. In order to ensure the comparability of the data, the year in which the financial data of the pairing companies selected from should be the same with that of the sample companies. Secondly, the pairing companies and sample companies must be in the same industry. Thirdly, the pairing company's current ratio must be nearly the same with the current ratios in the beginning of the year when sample companies issued MTNs, the magnitude of the difference does not exceed $\pm 15 \%$.

\subsection{The Definitions of Variables}

According to the research assumptions, from the perspective of reflecting the company' operation condition, financial condition and corporate governance, the paper chooses the following variables (Table 1). 
Table1. Definition of variables

\begin{tabular}{|c|c|c|c|}
\hline Variable Types & Variable Names & Symbols & Variable Description \\
\hline explained variable & Whether to issue MTNs & MTN & If the sample company issues MTNs, the value is 1 ; if not, the value is 0 . \\
\hline \multirow{7}{*}{$\begin{array}{l}\text { explanatory } \\
\text { variables }\end{array}$} & company size & SIZE & The natural logarithm of the sample company's total assets. \\
\hline & development prospect & TQ & The Tobin's Q of sample company at the end of the sample period. \\
\hline & cash flow & FLOW & Sample company' main business cash ratio in the sample period. \\
\hline & financial leverage & LEVA & $\begin{array}{l}\text { Sample company' ratio of the book value of liabilities and the book } \\
\text { value of assets in the sample period. }\end{array}$ \\
\hline & debt structure & DEBT & $\begin{array}{l}\text { Sample company' ratio of long-term debt and total book value of the } \\
\text { debt in the sample period. }\end{array}$ \\
\hline & ownership concentration & STOCK & $\begin{array}{l}\text { Sample company' the largest shareholder holding proportion of shares } \\
\text { up to the end of } 2011(\%) \text {. }\end{array}$ \\
\hline & equity property & STATE & $\begin{array}{l}\text { If the sample company' largest shareholder is state shares or state-owned } \\
\text { shares, the value is } 1 \text {; if not, is } 0 .\end{array}$ \\
\hline \multirow{5}{*}{$\begin{array}{l}\text { controlled } \\
\text { variables }\end{array}$} & overall profitability & ROA & $\begin{array}{l}\text { Sample company' earnings before interest and tax (EBIT) ratio in the } \\
\text { sample period (the ratio of EBIT and the average total assets). }\end{array}$ \\
\hline & main business profitability & EARN & Sample company' the main business profitability in the sample period \\
\hline & growth capacity & GROW & $\begin{array}{l}\text { Sample company' fixed asset investment expansion rate in the sample } \\
\text { period[(the total fixed assets in the bulletin issued year - the total fixed } \\
\text { assets a year ago)/ the total fixed assets a year ago]. }\end{array}$ \\
\hline & company age & AGE & $\begin{array}{l}\text { The years from the date of sample company establishment to the date of } \\
\text { issuing bulletin. }\end{array}$ \\
\hline & Industry dummy variable & $\begin{array}{l}\text { Dum } \\
\text { INDL }\end{array}$ & $\begin{array}{l}\text { When the industry which the sample company belongs to is the } \\
\text { manufacturing, the value is } 1 \text {, otherwise the value is } 0 \text {. }\end{array}$ \\
\hline
\end{tabular}

\subsection{Descriptive Statistics and Analysis}

Table 2 lists descriptive statistics and difference tests (T test and Mann-Whitney nonparametric test) of the sample companies and pairing companies' main variables. Comparing the listed companies which issued MTNs with the pairing companies, significant differences in business and other aspects could be found easily. Specifically, companies which issue MTNs have more assets, better development prospects, shorter operating life.

Table 2. Descriptive statistics and difference tests of variables

\begin{tabular}{|c|c|c|c|c|c|c|c|c|c|c|c|}
\hline \multirow{2}{*}{ variables } & \multicolumn{3}{|c|}{ All companies $(\mathrm{N}=148)$} & \multicolumn{3}{|c|}{ Sample companies $(\mathrm{N}=74)$} & \multicolumn{3}{|c|}{ Pairing companies $(\mathrm{N}=74)$} & \multirow{2}{*}{$\begin{array}{l}\text { Sample } \\
\text { T-test }\end{array}$} & \multirow{2}{*}{$\begin{array}{l}\text { M-W test } \\
\text { ( } \mathrm{Z} \text { value) }\end{array}$} \\
\hline & $\min$ & $\max$ & average & $\min$ & $\max$ & average & $\min$ & $\max$ & average & & \\
\hline SIZE & 19.224 & 27.809 & 23.041 & 20.720 & 27.809 & 23.739 & 19.224 & 26.463 & 22.342 & $-6.101 * * *$ & $-5.553 * * *$ \\
\hline TQ & -0.078 & 11.167 & 1.478 & 0.190 & 4.301 & 1.184 & 0.078 & 11.167 & 1.772 & $2.636^{*}$ & $-2.612 * * *$ \\
\hline FLOW & -0.165 & 0.807 & 0.153 & -0.122 & 0.638 & 0.137 & -0.165 & 0.807 & 0.169 & 1.006 & -0.694 \\
\hline LEVA & 0.182 & 1.063 & 0.566 & 0.198 & 0.888 & 0.559 & 0.182 & 1.063 & 0.574 & 0.508 & -0.514 \\
\hline DEBT & 0.000 & 0.823 & 0.290 & 0.000 & 0.785 & 0.317 & 0.001 & 0.823 & 0.263 & -1.42 & $-1.661 *$ \\
\hline STOCK & 3.62 & 86.35 & 39.601 & 11.39 & 86.35 & 41.303 & 3.62 & 75.1 & 37.9 & -1.228 & -1.053 \\
\hline STATE & 0 & 1 & 0.649 & 0 & 1 & 0.716 & 0 & 1 & 0.581 & -1.728 & $-1.716^{*}$ \\
\hline $\mathrm{ROA}$ & -11.18 & 42.82 & 7.932 & -11.18 & 24.22 & 7.059 & -1.76 & 42.82 & 8.805 & 1.732 & -1.515 \\
\hline EARN & -0.327 & 1.247 & 0.108 & -0.175 & 0.558 & 0.105 & -0.327 & 1.247 & 0.111 & 0.220 & -0.364 \\
\hline GROW & -0.694 & 1.626 & 0.127 & -0.220 & 1.147 & 0.162 & -0.694 & 1.626 & 0.092 & -1.570 & $-1.695 *$ \\
\hline $\mathrm{AGE}$ & 2.00 & 31.00 & 14.007 & 2 & 21 & 12.338 & 5 & 31 & 15.676 & $3.954 * * *$ & $-3.200 * * *$ \\
\hline Dum INDUSTRY & 0 & 1 & 0.338 & 0 & 1 & 0.338 & 0 & 1 & 0.338 & 0.000 & 0 \\
\hline
\end{tabular}

$*, * *, * * *$ represent the $10 \%, 5 \%, 1 \%$ significance level respectively.

\subsection{Correlation Analysis}

In the process of Pearson correlation analysis of the main variables (Table 3 ), we can find: in the aspect of operating characteristics of companies, whether the listed companies issue MTNs is negatively correlated with company size, business prospects, but there is no significant correlation with cash flow. In the aspect of finance, there is no significant correlation between whether the listed companies issue MTNs and financial leverage, debt maturity. In the aspect of corporate governance characteristics, there is no significant correlation between whether the listed companies issue MTNs and ownership concentration, equity property. In other characteristics, whether the listed companies issue MTNs is negatively correlated with company age. 
Table 3. Pearson correlation analysis of the variables

\begin{tabular}{|l|l|l|l|l|l|l|l|l|l|l|l|l|l|}
\hline & MIN & SIZE & LEVA & FLOW & TQ & DEBT & STOCK & STATE & ROA & EARN & GROW & AGE & $\begin{array}{l}\text { Dum } \\
\text { INDUSTRY }\end{array}$ \\
\hline MIN & 1 & & & & & & & & & & & & \\
\hline SIZE & $-.451^{* *}$ & 1 & & & & & & & & & & & \\
\hline LEVA & -.042 & $.181^{*}$ & 1 & & & & & & & & & & \\
\hline FLOW & -.083 & -.070 & $-.225^{* *}$ & 1 & & & & & & & & & \\
\hline TQ & $-.213^{* *}$ & $-.236^{* *}$ & $-.238^{* *}$ & .037 & 1 & & & & & & & & \\
\hline DEBT & .117 & $.206^{*}$ & -.018 & $.539^{* *}$ & -.076 & 1 & & & & & & & \\
\hline STOCK & .101 & $.452^{* *}$ & -.006 & -.016 & -.066 & .077 & 1 & & & & & & \\
\hline STATE & .142 & .117 & .002 & -.056 & .027 & .105 & $-.193^{*}$ & 1 & & & & & \\
\hline ROA & -1.42 & -.089 & -.388 & .136 & $.327^{* *}$ & .022 & .100 & .092 & 1 & & & & \\
\hline EARN & -.018 & -.091 & $-.428^{* *}$ & $.701^{* *}$ & .026 & $.417^{* *}$ & .022 & -.095 & $.204^{*}$ & 1 & & & \\
\hline GROW & .129 & .023 & $-.189^{*}$ & .076 & .039 & .111 & -.005 & -.083 & .027 & .127 & 1 & & \\
\hline AGE & $-.311^{* *}$ & $-.407^{* *}$ & .046 & .009 & .058 & -.113 & $-.038^{* *}$ & -.120 & .121 & -.035 & -.151 & 1 & \\
\hline $\begin{array}{l}\text { Dum } \\
\text { INDUSTRY }\end{array}$ & -.000 & -.139 & -.054 & $-.264^{* *}$ & -.077 & $-.296^{* *}$ & $-.219^{* *}$ & -.103 & -.024 & $-.191^{*}$ & -.001 & .122 & 1 \\
\hline
\end{tabular}

$*, * *, * * *$ represent the $10 \%, 5 \%, 1 \%$ significance level respectively (two-tailed).

\subsection{Regression Results Analysis}

Through Pearson analysis, the paper finds a high correlation between FLOW and EARN, the correlation value is up to 0.701 , in order to overcome the effects of multicollinearity, we construct Model 1 and Model 2 (Table 4) to test the model results. Through the Logistic analysis to Model 1 and Model 2, we find that both the two models' overall tests (Omnibus Tests) likelihood ratio chi-square statistic is significant at the 0.01 level, while both the two models' Nagelkerke $\mathrm{R}^{2}$ are around 0.45 , but model 1 's effect is better than model 2's effect $(0.454>0.446)$, and in the prediction accuracy, model 2 is better than model $1(76.4 \%>$ $75 \%)$

In summary, we can find: (1) Company size has the positive impact on the probability of issuing MTNs. The companies with the larger size have the advantage of scale and get more public attention, the level of information asymmetry is relatively low, which makes the possibility of companies to issue MTNs higher. (2) Companies having good development prospects have smaller Probability to issue MTNs. Possible explanation is that companies with good development prospects can finance from a variety of other methods or their cash flows are relatively abundant. (3) Financial leverage has a significant negative impact on the probability of listed companies' issuing MTNs. Lower debt leverage means companies can meet the regulation of issuing MTNs. On the other hand, lower financial leverage means the listed companies have stronger solvency and smaller pressure on the other debt payment, so they are more likely to seek new debt financing. (4) There is no correlation between the probability of issuing MTNs and debt maturity. The reason may be that Companies can refinance before maturity to repay the principal and interests of the last MTNs. (5) There is significant negative correlation between the probability of listed companies' issuing MTNs and ownership concentration. For a company with good internal governance environment, MTNs may not be the preferred solution to optimize corporate financial structure. (6) The equity property has no effect on whether a company issues MTNs. This shows that the corporate property may not be one of the determinants of whether a company issues MTNs. (7) Main business profitability and the probability of listed companies' issuing MTNs are negatively correlated. This result is supported by Model 2, but not by Model 1. 
Table 4. Logistic model estimation results

\begin{tabular}{|c|c|c|c|c|c|c|c|c|}
\hline \multirow{2}{*}{ Variables } & \multicolumn{4}{|l|}{ Model 1} & \multicolumn{4}{|l|}{ Model 2} \\
\hline & Coefficient & Standard error & Wald-value & P-value & Coefficient & Standard error & Wald-value & P-value \\
\hline Constant & -18.646 & 4.847 & 14.800 & 0.000 & -18.958 & 4.875 & 15.121 & 0.000 \\
\hline SIZE & 1.076 & 0.241 & 19.907 & 0.000 & 1.075 & 0.239 & 20.286 & 0.000 \\
\hline TQ & -0.302 & 0.160 & 3.569 & 0.059 & -0.294 & 0.160 & 3.388 & 0.066 \\
\hline FLOW & -1.765 & 1.461 & 1.460 & 0.227 & & & & \\
\hline LEVA & -4.582 & 1.696 & 7.297 & 0.007 & -4.273 & 1.735 & 6.064 & 0.014 \\
\hline DEBT & 0.853 & 1.130 & 0.570 & 0.450 & 0.193 & 1.053 & 0.033 & 0.855 \\
\hline STOCK & -0.041 & 0.016 & 6.449 & 0.011 & -0.039 & 0.016 & 3.388 & 0.013 \\
\hline STATE & 0.726 & 0.447 & 2.632 & 0.105 & 0.747 & 0.447 & 2.789 & 0.095 \\
\hline $\mathrm{ROA}$ & -0.079 & 0.046 & 2.956 & 0.086 & -0.078 & 0.045 & 3.072 & 0.080 \\
\hline EARN & & & & & -0.456 & 1.702 & 0.072 & 0.789 \\
\hline GROW & 0.651 & 0.783 & 0.691 & 0.406 & 0.738 & 0.764 & 0.934 & 0.334 \\
\hline AGE & -0.102 & 0.049 & 4.363 & 0.037 & -0.102 & 0.048 & 4.441 & 0.035 \\
\hline Dum INDUSTRY & 0.096 & 0.465 & 0.043 & 0.836 & 0.169 & 0.462 & 0.134 & 0.715 \\
\hline Chi-square & \multicolumn{4}{|l|}{61.687} & \multicolumn{4}{|l|}{60.242} \\
\hline -2Log Likelyhood & \multicolumn{4}{|l|}{143.484} & \multicolumn{4}{|l|}{144.930} \\
\hline Cox\&SnellR square & \multicolumn{4}{|l|}{0.341} & \multicolumn{4}{|l|}{0.334} \\
\hline NagelkerkeRsquare & \multicolumn{4}{|l|}{0.454} & \multicolumn{4}{|l|}{0.446} \\
\hline Percentage Correct & \multicolumn{4}{|l|}{$75 \%$} & \multicolumn{4}{|l|}{$76.4 \%$} \\
\hline
\end{tabular}

\section{CONCLUSION}

From business situation, financial condition and corporate governance, this paper analyzes the key factors that determine the listed companies financing decisions of issuing MTNs. The results show that: company size, growth prospects, financial leverage, ownership concentration are the main driving factors that determine the listed companies' financing decisions of issuing MTNs. Specifically companies with large company size, good growth prospects, low financial leverage, good corporate governance are more likely to choose MTNs as debt financing instruments. In addition, the main business profitability is uncertain to have impact on companies' issuing MTNs. Company's cash flow and debt structure have no significant effect on the decision of issuing MTNs.

\section{REFERENCES}

[1] Baxter, N. D. and J. G. Cragg. 1970. Corporate choice among long-term financing instruments. Review of Economics and Statistics (52): 225-235.

[2] Chen, X. Y. and X. D. Xu. 2001. Ownership Structure, Corporate Performance and the Protection of Investors' interests. Economic Research Journal(11): 3-11.
[3] Datta, Sudip, Mai Iskandar-Datta and Ajay Patel. 2000. Some Evidence on the Uniqueness of Initial Public Debt Offerings. The Journal of Finance55(2): 715-743.

[4] Denis, D. J. and V. T. Mihov. 2003. The choice among bank debt, non-bank private debt, and public debt: evidence from new corporate borrowings. The Journal of Finance Economics 70(1): 3-28.

[5] Dong, M. S. and Z. P. Li. 2005. A Positive Investgation of the Relationship between Corporate Performance and Ownership Structure. Journal of Anhui University of Technology(Natural Science)(1): 76-80.

[6] Guo, L. H. and W. J. Ma. 2009. Financing Constraints and Corporate Investment - Cash Flow Sensitivity Retesting: Evidence From Chinese Listed Companies. Journal of World Economy(2): 77-87.

[7] Krishnaswami, Sudha, Paul A. Spindt and Venkat Subramaniam. 1999. Information asymmetry, monitoring and the placement structure of corporate debt. Journal of Financial Economics(51): 407-434.

[8] Liao, S. G.. 2011. Research on the Factors of Listed Companies Medium Term Notes Financing. Securities Market Herald(3): 57-63.

[9] Mizen, Paul and S. Tsoukas. What promotes greater use of the corporate bond market? A study of the issuance behaviour of firms in Asia. Oxford Economic Papers, 2013.

[10] Tu, L. P., Xin, Y. and G. M. Chen. 2006. Ownership Concentration, Outside Blockholders, and Operating Performance: Evidence from China's Listed Companies. Economic Research Journal(1): 90-100.

[11] Xiao, Z. P. and S. N. Wu. 2002. An Empirical Study on Chinese Listed Companies' Capital Structure Factors. Securities Market Herald(8): 39-44. 